\author{
V. Vladimirov, V. Matevski, S. Bancheva, M. Delcheva, M. Kostadinovski \\ \& R. Ćušterevska
}

\title{
First report of Erigeron sumatrensis (Asteraceae) for the flora of the Republic of Macedonia
}

\begin{abstract}
Vladimirov, V., Matevski, V., Bancheva, S., Delcheva, M., Kostadinovski, M. \& Ćušterevska, R.: First report of Erigeron sumatrensis (Asteraceae) for the flora of the Republic of Macedonia. - Fl. Medit. 26: 203-207. 2016. — ISSN: 1120-4052 printed, 2240-4538 online.

Erigeron sumatrensis (Asteraceae) is reported for the first time for the flora of the Republic of Macedonia. The taxon was recorded in several localities across the country. It seems, the species was introduced several decades ago, however, it remained unrecognized, mainly due to mis-identification with E. bonariensis. Brief morphological description, based on the material collected from Macedonia, and the habitat preferences of the species are provided. Erigeron sumatrensis has viable and persistent populations and should be regarded as naturalized in the Macedonian flora. The invasive behavior of the species is discussed briefly.
\end{abstract}

Key words: alien plants, Conyza, Conyza sumatrensis, Macedonian flora, xenophytes.

\section{Introduction}

Although the flora of the Republic of Macedonia is relatively well studied, ongoing research into the plant diversity of the county for the preparation of the critical national Flora continues to provide floristic novelties. Recently, four new taxa - Andrachne telephioides L., Chorispora tenella (Pallas) DC., Nepeta parviflora M. Bieb. and Marrubium pestalozzae Boiss. - were reported (Matevski 2016). During field studies within a bilateral Bulgarian-Macedonian project devoted to the taxonomic diversity in the families Lamiaceae and Asteraceae, a new alien species for the Macedonian flora was recorded next to a petrol station near the highway in Veles Municipality - Erigeron sumatrensis Retz. Later examination of the collection in the herbarium MKNH revealed the species had been recorded much earlier from several localities in the country but it was erroneously identified as Conyza bonariensis (L.) Cronquist.

The aim of this article is to report Erigeron sumatrensis (Asteraceae) as a new alien species to the flora of the Republic of Macedonia and to highlight its main distinguishing characters from morphologically similar taxa. 


\section{Material and methods}

Plant material collected by the authors in the field as well as the material stored in the Herbarium (MKNH) of the Institute of Biology, Faculty of Natural Sciences and Mathematics in Skopje was investigated. Morphological characters were noted from the examined specimens and compared with those from relevant taxonomic literature (Marshall 1973; Davis \& al. 1988; Wurzell 1988; Milović 2004; Vladimirov \& Kuzmanov 2012). Data about the habitats of the species is based on the authors' personal observations. Plant nomenclature and taxonomy is consistent with Euro+Med Plant base (Greuter 2006-).

\section{Results and discussion}

Erigeron sumatrensis Retz., Observ. Bot. 5: 28 (1788) [syn.: Conyza sumatrensis (Retz.) E. Walker; C. albida Spreng.; Erigeron albidus (Spreng.) A. Gray].

Annual to biennial. Stems $50-180 \mathrm{~cm}$, branched above, grayish-green, densely hairy, with two types of eglandular simple hairs - dense, appressed, pointing upward short hairs, and sparse, patent longer hairs. Leaves numerous, simple, alternate, $4-10 \times 0.6-1.2 \mathrm{~cm}$, elliptic-lanceolate to lanceolate, remotely dentate, lower petiolate, the uppermost sessile, pubescent. Synflorescence paniculate, rhombic in outline, many-flowered. Involucral bracts in 2-3 rows, linear-lanceolate, 3-5 mm long, densely pubescent, grayish-green. Ligulate florets numerous, female, in several rows, ligule shorter than $0.5 \mathrm{~mm}$ (inconspicuous); tubular florets few (ca. 15), hermaphrodite. Achenes obovate, compressed, 1-1.5 $\mathrm{mm}$ long, with a pappus of $4-5 \mathrm{~mm}$ long, pale-brownish hairs. Flowering June to November, fruiting July to November.

In the Macedonian flora, E. sumatrensis is morphologically most similar to two alien, congeneric species - E. canadensis L. and E. bonariensis. Erigeron canadensis differs from the other two species by having glabrous to subglabrous involucral bracts, green stem with sparse patent hairs, and conspicuous, $0.5-1 \mathrm{~mm}$ long whitish ligules. Erigeron sumatrensis differs from $E$. bonariensis in having rhombic in outline synflorescence, with side branches not exceeding the central branch (funnel-shaped in E. bonariensis, with side branches usually much overtopping the central branch), most peduncles 1-2 times longer than capitula in fruiting stage (peduncles 2-6 times longer than capitula in E. bonariensis), grayish-green involucral bracts (usually purple-tipped in E. bonariensis), receptacle 1.8$2.8 \mathrm{~mm}$ wide (2.6-3.9 mm wide in E. bonariensis) and pale-brownish pappus hairs (dirtywhite in E. bonariensis).

Distribution in the Republic of Macedonia: - Skopje, in the city centre (near Sajmište), 20 Nov 1992, coll. V. Matevski; Skopje, Gazi Baba, 25 Sept 1999, coll. V. Matevski; Gradsko: Stobi, by a pathway, 140 m a. s. 1., 30 Jun 1999, coll. V. Matevski; Star Dojran, Mrdaja, sandy places in front of Mlaz hotel, 22 Sept 1999, leg. V. Matevski; Star Dojran, Mrdaja, in front of Mlaz hotel, on the sands around the lake, 02 Dec 2000, leg. V. Matevski; Kočani, between Kočani town and Istibanja village, by the road, $375 \mathrm{~m}$ a. s. $1 ., 41^{\circ} 55^{\prime} 07^{\prime \prime} \mathrm{N}, 22^{\circ} 29^{\prime} 30^{\prime \prime} \mathrm{E}, 15$ Oct 2005, coll. V. Matevski \& M. Kostadinovski; Makedonska Kamenica, between Istibanja village and Makedonska Kamenica, by the road, $389 \mathrm{~m}$ a. s. $1 ., 41^{\circ} 56^{\prime} 00^{\prime \prime} \mathrm{N}, 22^{\circ} 30^{\prime} 50^{\prime \prime} \mathrm{E}, 15$ 
Oct 2005, coll. V. Matevski \& M. Kostadinovski; Veles: Gradsko, near the junction to Prilep, $167 \mathrm{~m}$ a. s. $1 ., 41^{\circ} 33^{\prime} 15^{\prime \prime} \mathrm{N}, 21^{\circ} 57^{\prime} 30^{\prime \prime}$ E, 06 Oct 2006, coll. V. Matevski; Veles: Dolno Kalaslari village, by a petrol station near Aleksandar Makedonski

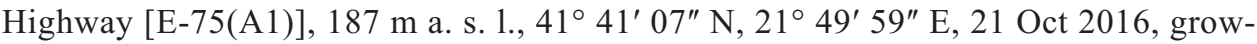
ing together with E. canadensis and E. bonariensis, V. Vladimirov, M. Delcheva, $S$. Bancheva (SOM) (Fig.1).

If not otherwise stated, the examined herbarium specimens have been stored in the Herbarium (MKNH) of the Institute of Biology, Faculty of Natural Sciences and Mathematics in Skopje and in the herbarium (SOM) of the Institute of Biodiversity and Ecosystem Research, Bulgarian Academy of Sciences, Sofia.

Apparently the species was introduced long ago, however, it remained unrecognized by E. bonariensis, mainly due to the lack of relevant taxonomic literature, e.g. in Cronquist (1976) only E. canadensis and E. bonariensis were included.

Distribution worldwide: - Native to South America. Introduced and naturalized to all continents except for Antarctica (Thébaud \& Abbott 1995; Pruski \& Sancho 2006). In the Balkan Peninsula, E. sumatrensis was recorded in almost all countries: Albania (Baltisberger \& Lippert 1987), Bulgaria (Vladimirov 2009; Petrova \& al. 2013), Croatia (Milović 2004), Greece (Danin 1976, 1983), Montenegro (Stešević \& Petrović 2010, sub Conyza albida), Romania (Anastasiu \& Memedemin 2012), Serbia (Niketić \& Jovanović 2002; Vrbničanin \& al. 2004), Slovenia (Poldini \& Kaligarič 2000), Turkey-in-Europe (Davis \& al. 1988: 161-162).

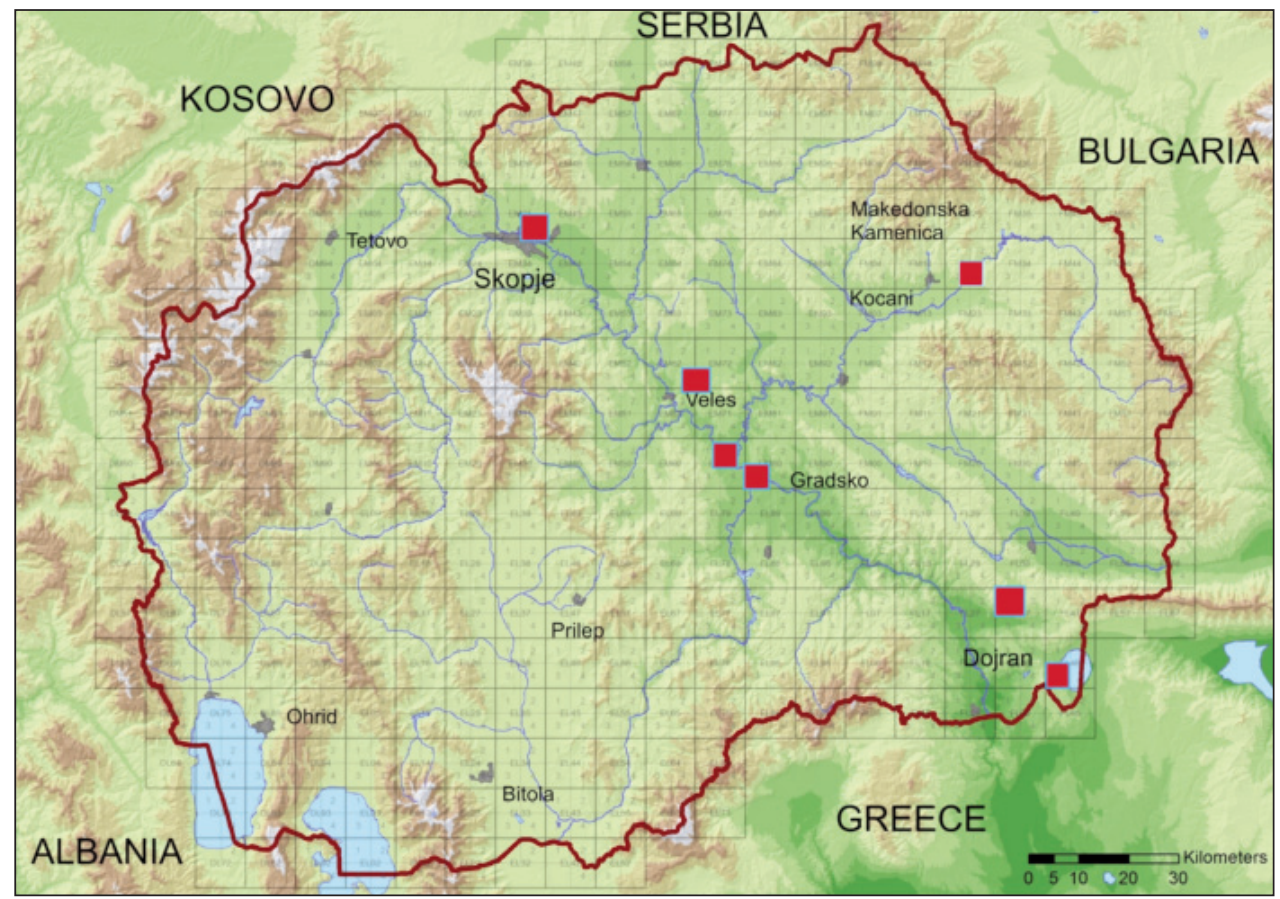

Fig. 1. Distribution of Erigeron sumatrensis in the Republic of Macedonia. 
Habitat preferences: - Erigeron sumatrensis grows in open, sunny to partly shaded places, mainly in disturbed or man-made habitats - road embankments, railroad tracks, urban areas, waste lands, arable land, row crops, vineyards and orchards. In many of these sites, E. sumatrensis grows together with E. canadensis and/or E. bonariensis, and in these cases it usually reaches the biggest size of the three species.

Invasiveness: - The observed populations of the species in Macedonia are viable and persistent, not dependent on further introductions or maintenance by humans, which suggests that the species should be regarded as naturalized in the Macedonian flora in the sense of Richardson \& al. (2000). Invasive behavior of the species has been reported for some of the neighbouring countries, e.g. for Bulgaria (Vladimirov 2009; Petrova \& al. 2013). In fact, $E$. sumatrensis and E. canadensis are considered the most widespread species throughout the world (Thébaud \& Abbott 1995) included the small Mediterranean islands (Celesti-Grapow \& al. 2016). Each specimen of the taxon produces an enormous amount of seeds which are very easily dispersed by wind. This, as well as other reproductive traits, e.g. autonomous seed production, versatile mating system of self- and cross-pollination, generalized pollination system, high germination rate (Hao \& al. 2009), make the species a very efficient colonizer in open, disturbed or free of vegetation places. However, the species is less competitive than native plants if the disturbance of the ground is discontinued. Therefore, E. sumatrensis is not or very rarely seen in most of the well preserved natural habitats, e.g. grasslands. However, it may become invasive in natural sparsely vegetated habitats. The species is an important and highly aggressive weed in agricultural land.

\section{Acknowledgements}

Financial support by the Macedonian Academy of Sciences and Arts and by the Bulgarian Academy of Sciences under the project 'Floristic and taxonomic studies of selected genera from the families Lamiaceae and Asteraceae in the border regions of Macedonia and Bulgaria' is gratefully acknowledged.

\section{References}

Anastasiu, P. \& Memedemin, D. 2012: Conyza sumatrensis: a new alien plant in Romania. - Bot. Serbica 36(1): 37-40.

Baltisberger, M. \& Lippert, W. 1987: Compositen aus Albanien. - Candollea 42(2): 679-691.

Celesti-Grapow, L., Bassi, L., Brundu, G., Camarda, I., Carli, E., D’Auria, G., Del Guacchio, E., Domina, G., Ferretti, G., Foggi, B., Lazzato, L., Mazzola, P., Peccenini, S., Pretto, F., Stinca, A. \& Blasi, C. 2016: Plant invasions on small Mediterranean islands: An overview. - Pl. Biosyst. 150(5): 1119-1133. doi: 10.1080/11263504.2016.1218974

Cronquist, A. 1976: Conyza Less. - P. 120 in: Tutin, T. G., Heywood, V. H., Burges, N. A., Moore, D. M., Valentine, D. H., Walters, S. M. \& Webb., D. A. (eds), Flora Europaea, 4. - Cambridge.

Danin, A. 1976: On three adventive species of Conyza (Compositae) in Greece. - Candollea 31: 107-109. - 1983: Conyza albida Sprengel. - P. 283 in: Greuter, W. \& Raus, Th. (eds), Med-Checklist Notulae, 8. - Willdenowia 13(2): 277-288.

Davis, P. H., Mill, R. R. \& Tan, K. 1988: Flora of Turkey and the East Aegean Islands, 10. - Edinburgh. Greuter, W. 2006-: Compositae (pro parte majore). - In: Greuter, W. \& Raab-Straube, E. von (ed.), Compositae. Euro+Med Plantbase - the information resource for Euro-Mediterranean plant diversity. - http://www.emplantbase.org/home.html [Accessed 15/11/2016]. 
Hao, J.-H., Qiang, Sh., Liu, Q.-Q. \& Cao, F. 2009: Reproductive traits associated with invasiveness in Conyza sumatrensis. - J. Syst. Evol. 47(3): 245-254. doi: 10.1111/j.17596831.2009.00019.x

Marshall, J. B. 1973: Conyza taxa found in Britain. - Watsonia 9: 372-373.

Matevski, V. 2016: New and rare plant taxa for the flora of the Republic of Macedonia. - Pp. 65-66 in: Abstract Book. V Congress of Ecologists of the Republic of Macedonia with International Participation, 19-22.10.2016, Ohrid. - Skopje.

Milović, M. 2004: Naturalised species from the genus Conyza Less. (Asteraceae) in Croatia. - Acta Bot. Croat. 63(2): 147-170.

Niketić, M., Jovanović, S. 2002: Conyza sumatrensis, a new adventive species in the flora of Serbia. - P. 23 in: VII Symposium on the flora of Southeast Serbia and neighbouring countries with international participation. Abstracts. Dimitrovgrad [Conyza sumatrensis nova adventivna vrsta u flori Srbije. - VII Simpozijum o flori jugoistočne Srbije i susednih područja sa međunarodnim učešćem, Zbornik rezimea, Dimitrovgrad, 23].

Petrova, A., Vladimirov, V. \& Georgiev, V. 2013: Invasive Alien Species of Vascular Plants in Bulgaria. - Sofia.

Poldini, L. \& Kaligarič, M. 2000: Bidens pilosa and Conyza sumatrensis, two new naturalized species in the flora of Slovenia. - Annales 10: 77-80.

Pruski, J. F. \& Sancho, G. 2006: Conyza sumatrensis var. leiotheca (Compositae: Astereae), a new combination for a common neotropical weed. - Novon 16(1): 96-101.

Richardson, D. M., Pyšek, P., Rejmánek, M., Barbour, M. G., Dane Penetta, F. \& West, C. J. 2000: Naturalization and invasion of alien plants: concepts and definitions. - Diversity \& Distrib. 6: 93-107.

Stešević, D. \& Petrović, D. 2010: Preliminary list of plant invaders in Montenegro. - Biol. Nyssana 1(1-2): $35-42$.

Thébaud, C. \& Abbott, R. J. 1995: Characterization of invasive Conyza species (Asteraceae) in Europe: quantitative trait and isozyme analysis. - Amer. J. Bot. 82: 360-368.

Vladimirov, V. 2009: Erigeron sumatrensis (Asteraceae): a recently recognized alien species in the Bulgarian flora. - Phytol. Balcan. 15(3): 361-365.

— \& Kuzmanov, B. 2012: Erigeron L. - Pp. 196-208 in: Kožuharov, S. \& Ančev, M. (eds), Fl. Reipubl. Bulgaricae, 11. - Sofia.

Vrbničanin, S., Karadžić, B. \& Dajić-Stevanović, Z. 2004: Adventive and invasive weed species in Serbia. - Acta Herbologica 13(1): 1-12.

Wurzell, B. 1988: Conyza sumatrensis (Retz.) E. Walker established in England. - Watsonia 17: $145-148$.

Addresses of the authors:

Vladimir Vladimirov ${ }^{1}$, Vlado Matevski ${ }^{2}, 3$, Svetlana Bancheva ${ }^{1}$, Malina Delcheva $^{1}$, Mitko Kostadinovski $^{3}$ \& Renata Ćušterevska ${ }^{3}$,

${ }^{1}$ Department of Plant and Fungal Diversity and Resources, Institute of Biodiversity and Ecosystem Research, Bulgarian Academy of Sciences, Acad. Georgi Bonchev St., bl. 23, 1113 Sofia, Bulgaria. E-mail: vladimir_dv@abv.bg

${ }^{2}$ Research Center for Environment and Materials, Macedonian Academy of Sciences and Arts, Krste Misirkov 2, 1000 Skopje, R. Macedonia.

${ }^{3}$ Institute of Biology, Faculty of Natural Sciences and Mathematics, Ss. Cyril and Methodius University, 1000 Skopje, R. Macedonia. 
